\title{
PENGARUH KEPEMIMPINAN, MOTIVASI DAN DISIPLIN KERJA TERHADAP KINERJA GURU SMK FARMASI IKASARI PEKANBARU
}

\author{
Rini Fatriani ${ }^{1}$, Fahrial $^{2}$ \\ ${ }^{1}$ Dosen STIE Riau, ${ }^{2}$ Dosen Faperta Agribisnis UIR \\ Email : rinifatriani@yahoo.co.id ${ }^{1}$, fahrial2018@ agr.uir.ac.id $^{2}$
}

\begin{abstract}
The population in this study are all teachers SMK Farmasi Ikasari Senior High School Pekanbaru, amounting to 55 people. Sampling was performed using saturated sample. Data analysis is done by using validity, reliability, classical assumptions, multiple linear regression, $F$ test and $t$-test. The tests are performed in order to determine the relationship between the independent variable with the dependent variable. Based on the result of the research, the leadership, motivation, and performance are influenced on teacher's performance. It is proved by finding the score of $R=0.769$. It means that there was a correlation among leadership, motivation and discipline on teachers' performance at SMK Farmasi Ikasari Senior High School Pekanbaru. Meanwhile the score of $R$ was $56,7 \%$. It means that there was a contribution of leadership, motivation, and discipline on teachers' performance. Furthermore, it has positive contribution on teachers' performance by finding $F$ score is 24.800 and level significant is 0.000. Partially, there was a positive significant effect of leadership variable, motivation, and discipline on teachers; performance at SMK Farmasi Ikasari Senior High School pekanbaru. The details of the linear regression as follow: $Y=14.359+0,149 X 1+0,185 X 2+0,376 X 3$ and sig. $0.048,0.040,0.000$ are lower than Alpha 5\%. The conclusion of the research was the hypothesis partially and altogether among leadership variable, motivation, and discipline on teachers' performance was proved and accepted.
\end{abstract}

Keywords: Leadership, Motivation, Discipline and Teachers'Performance

\section{PENDAHULUAN}

Penerapan disiplin dalam kehidupan organisasi ditujukan agar semua pegawai yang ada dalam organisasi bersedia dengan sukarela mematuhi dan mentaati segala peraturan dan tata tertib yang berlaku tanpa ada paksaan. Dalam kaitan ini disiplin sangat diperlukan dalam suatu organisasi, karena untuk mencapai tujuan dan sasaran yang telah ditetapkan. Pegawai yang disiplin akan mentaati semua normanorma dan nilai-nilai serta aturan yang telah ditetapkan dalam organisiasi. Penegakan disiplin kerja tidak diserahkan kepada pegawai semata. Untuk organisasi harus memiliki pola pembinaan kepada para pegawainya, pola pembinaan disiplin dapat berupa:

a. Membuat peraturan-peraturan atau Standar Operasional Prosedur (SOP) oleh perusahaan

b. Memberikan sanksi bagi pelanggar peraturan.

c. Melakukan pembinaan kedisiplinan melalui pelatihan secara terus-menerus dan berkesinambungan.

Adapun peraturan-peraturan yang berkaitan dengan disiplin antara lain:

a. Peraturan tentang jam masuk dan pulang serta jam istirahat 
b. Peraturan dasar tentang berpakaian dan bertingkahlaku dalam bekerja

c. Peraturan tentang cara-cara melakukan pekerjaan dan berhubungan dengan unit kerja lain

d. Peraturan tentang perintah dan larangan para pegawai selama dalam organisasi dan sebagainya.

Dalam peningkatan disiplin, SMK Farmasi Ikasari Pekanbaru telah menetapkan peraturan tentang jam masuk, jam istirahat dan jam pulang dan aturan berpakaian untuk guru, yaitu:

a. Masuk kantor jam 07.00 WIB, jadi bagi guru dan pegawai SMK Farmasi Ikasari Pekanbaru hadir sebelum jam 06.50 WIB b. Istirahat jam 09.30-10.00 WIB dan 12.30-13.00 WIB

c. Pulang kantor jam 15.00 WIB.

d. Khusus hari Jumat jam istirahat siang jam 11.30-13.30 WIB

e. Hari Senin dan Selasa menggunakan seragam PDH, Rabu dan Kamis menggunakan seragam batik, Jumat seragam Melayu dan Sabtu seragam bebas sesuai dengan kegiatan ektrakurikuler yang diampu.

Bagi guru dan pegawai yang tidak memiliki pakaian seragam yang telah ditentukan, dapat menggunakan pakaian lain yang sesuai dengan ketentuan. Berikut tabel kehadiran guru SMK Farmasi Ikasari Pekanbaru dari tahun 2010-2014.

Tabel 1.1.

Data Kehadiran Guru SMK Farmasi IkasariPekanbaru

\begin{tabular}{|c|c|c|c|c|c|c|c|c|}
\hline No & Tahun & $\begin{array}{c}\text { Jumlah } \\
\text { Guru }\end{array}$ & $\begin{array}{c}\text { Jumlah } \\
\text { Hari } \\
\text { efektif }\end{array}$ & $\begin{array}{c}\text { Jumlah } \\
\text { Hari } \\
\text { Kerja/ } \\
\text { Tahun }\end{array}$ & Absensi & Persentase & $\begin{array}{c}\text { Terlambat } \\
\text { dan Cepat } \\
\text { Pulang }\end{array}$ & Persentase \\
\hline 1 & $2010 / 2011$ & 47 & 250 & 11.750 & 564 & $4,80 \%$ & 312 & $2,65 \%$ \\
\hline 2 & $2011 / 2012$ & 53 & 248 & 13.144 & 578 & $4,39 \%$ & 285 & $2,67 \%$ \\
\hline 3 & $2012 / 2013$ & 73 & 246 & 17.958 & 624 & $3,47 \%$ & 242 & $1,35 \%$ \\
\hline 4 & $2013 / 2014$ & 52 & 250 & 15.500 & 540 & $3,48 \%$ & 385 & $2,48 \%$ \\
\hline 5 & $2014 / 2015$ & 55 & 252 & 15.624 & 750 & $4,80 \%$ & 458 & $2,93 \%$ \\
\hline
\end{tabular}

Sumber: Bagian Administrasi, 2015

Dari tabel diatas, dapat di lihat bahwa tingkat absensi guru pada SMK Farmasi Ikasari Pekanbaru mengalami peningkatan pada tahun 2013/2014 dan pada tahun 2014/2015. Sedangkan persentase keterlambatan dan cepat pulang juga mengalami kenaikan pada tahun 2013/2014 dan tahun 2014/2015. Hal ini disebabkan kurangnya kedisiplinan guru pada SMK Farmasi Ikasari Pekanbaru.

Hasil Kerja guru dapat dilihat dari perkembangan kinerjanya. Kinerja 
pegawai merupakan hasil dari kegiatan yang dilaksanakan. Kinerja timbul bukan saja bersumber dari pendidikan formal, namun dalam praktek kerjanya dilapangan, kinerja timbul dari adanya berbagai latihanlatihan bagi pegawai operasional dan pendidikan-pendidikan bagi para guru. Perkembaangan operasional bertujuan untuk menigkatkan hasil secara efektif, sedangkan pengembangan teknis bertujuan untuk meningkatkan konsep dan strategi dalam merencanakan dan pengembangan potensi yang ada pada seorang manager atau pimpinan sekolah (Kepala Sekolah).

Pada SMK Farmasi Ikasari Pekanbaru motivasi yang diberikan kepada guru dan pegawainya adalah sebagai berikut:
a. Kompensasi
b. Tunjangan jabatan dan wali kelas
c. Uang transfor
d. Tunjangan kepanitiaan
e. Tunjangan kelebihan jam mengajar.

Untuk mencapai tujuan organisasi, pimpinan dan guru-guru yang ada haruslah bekerja secara efektif dan efisien, sehingga kinerja mereka dapat ditingkatkan. Dengan peningkatan motivasi, baik motivasi secara material maupun motivasi secara spiritual, maka akan meningkatkan kinerja pegawai yang lebih baik. Semua faktor tersebut jika dimaksimalkan akan mampu mendukung kinerja pegawai.

Tabel 2.

Data Jumlah Guru dan Siswa SMK Farmasi Ikasaridari Tahun 2010-2014

\begin{tabular}{|c|c|c|c|}
\hline Tahun Pelajaran & Jumlah Guru & Jumlah Siswa & Kelulusan \\
\hline $2010 / 2011$ & 47 & 468 & 150 \\
\hline $2011 / 2012$ & 53 & 539 & 152 \\
\hline $2012 / 2013$ & 73 & 610 & 154 \\
\hline $2013 / 2014$ & 52 & 719 & 220 \\
\hline $2014 / 2015$ & 55 & 759 & 221 \\
\hline
\end{tabular}

Sumber: Bagian administrasi 2015

Dari tabel diatas dapat dilihat bahwa Jumlah guru SMK Farmasi Ikasari Pekanbaru pada tahun pelajaran 2010/2011 ke tahun pelajaran 2011/2012 bertambah 6 orang sedangkan dari tahun pelajaran 2012/2013 ke tahun pelajaran 2013/2014 berkurang 11 orang. Setelah itu tahun 2013/2014 ke tahun pelajaran 2014/2015 tidak ada penambahan guru, sedangkan jumlah siswa dan jumlah kelulusan siswa setiap tahunnya meningkat. Pada tahun 2014/2015 jumlah 221 adalah jumlah siswa yang mengukuti Ujian Nasional pada tahun 2015.

Selain motivasi keberhasilan atau kinerja guru juga dipengaruhi oleh disiplin kerja dan kepemimpinan suatu organisasi. Demikian juga pimpinan pada SMK Farmasi Ikasari Pekanbaru, dalam kebijakannya, 
dengan menggerakkan dan mengendalikan pegawainya perlu mendalami masalah-masalah yang berkaitan dengan kinerja guru. Kinerja dapat ditingkatkan melalui motivasi yang dilakukan oleh Pimpinan SMK Farmasi Ikasari Pekanbaru.
Masalah yang sering dihadapi dan berhubungan dengan kinerja diantaranya adalah pada hasil kerja guru masih ada yang mengalami penurunan, pencapaian target kerja masih mengalami hambatan, standar kerja juga masih ada yang tidak sesuai dengan harapan.

Tabel 3.

Data Laporan Guru yang Menyerahkan Perangkat Pembelajaran mulai tahun 2010-2014

\begin{tabular}{|c|c|c|c|}
\hline Tahun Pelajaran & Jumlah Guru & $\begin{array}{c}\text { Jlh. Guru yang } \\
\text { Menyerahkan RPP }\end{array}$ & $\begin{array}{c}\text { Jlh. Guru yang } \\
\text { Tidak Menyerahkan } \\
\text { RPP }\end{array}$ \\
\hline $2010 / 2011$ & 47 & 22 & 25 \\
\hline $2011 / 2012$ & 53 & 26 & 27 \\
\hline $2012 / 2013$ & 73 & 35 & 22 \\
\hline $2013 / 2014$ & 52 & 30 & 20 \\
\hline $2014 / 2015$ & 55 & 35 & 38 \\
\hline
\end{tabular}

Sumber: Bagian Kurikulum SMK Farmasi Ikasari, 2015

Dari tabel diatas dapat dilihat bahwa, masih banyak guru yang tidak menyerahkan perangkat pembelajaran, hal ini berarti masih banyak jumlah guru pada SMK Farmasi Ikasari Pekanbaru kurang disiplin dan kinerjanya belum maksimal. Kinerja yang belum maksimal disinyalir disebabkan oleh kepemimpinan, motivasi dan disiplin kerja guru yang masih rendah.

\section{KERANGKA PEMIKIRAN DAN KERANGKA TEORI}

A. Pengaruh Kepemimpinan Terhadap Kinerja Guru

Gaya hidup menurut Kotler (2012), Gaya kepemimpinan ialah pola perilaku dan strategi yang disukai dan sering diterapkan pemimpin, dengan menyatukan tujuan organisasi dengan tujuan individu atau pegawai, dalam rangka mencapai tujuan atau sasaran yang telah menjadi komitmen bersama. Rachmawati, dkk (2006).) telah meneliti gaya kepemimpinan terhadap kinerja pegawai, kemudian menyatakan bahwa gaya kepemimpinan mempunyai pengaruh positif dan signifikan terhadap kinerja pegawai.

Sedangkan menurut Thoha (2010:49), gaya kepemimpinan adalah norma perilaku yang digunakan oleh seseorang pada saat orang tersebut mencoba memengaruhi perilaku orang lain untuk mencapai tujuannya. 


\section{B. Pengaruh}

Terhadap Kinerja Guru

Keputusan pembelian adalah tindaka Motivasi dalam suatu perusahaan sangat diperlukan setiap karyawan dalam meningkatkan kinerja yang lebih baik. Menurut Stoner dalam Notoatmodjo (2009:125) mengatakan kinerja seorang karyawan atau tenaga kerja dipengaruhi oleh: motivasi, kemampuan, faktor persepsi.

Sedangkan menurut Tika (2010:122) bahwa faktor intern yang mempengaruhi kinerja guru adalah: kecerdasan, keterampilan, kestabilan emosi, motivasi, persepsi peran kondisi keluarga, kondisi fisik.

Shadare, dkk (2009), juga menyebutkan motivasi karyawan merupakan salah satu strategi untuk meningkatkan kinerja karyawan.

\section{Pengaruh Disiplin Kerja Terhadap Kinerja Guru}

Disiplin kerja merupakan salah satu aspek yang mempengaruhi kinerja karyawan. Zesbendri dan Aryanti (2009), menyebutkan bahwa disiplin merupakan modal utama yang mempengaruhi tingkat kinerja karyawan. Menurut Ardana, dkk (2011:134), disiplin kerja merupakani suatu sikap menghormati, menghargai, patuh, dan taat terhadap peraturan-peraturan yang berlaku, baik yang tertulis maupun yang tidak tertulis serta sanggup menjalankannya dan tidak mengelak untuk menerima sanksisanksinya.

Dari uraian tersebut, bahwa kepemimpinan, motivasi, dan disiplin kerja berpengaruh dalam peningkatan kinerja seorang karyawan dalam setiap perusahaan pada umumnya dan SMK Farmasi Ikasari Pekanbaru pada khususnya.

Hubungan antara gaya kepemimpinan, motivasi, dan disiplin kerja terhadap kinerja guru SMK Farmasi Ikasari Pekanbaru dapat digambarkan pada model/disain penelitian berikut:

\section{Gambar 1.}

Hubungan Gaya Kepemimpinan, Motivasi dan Disiplin Kerja terhadap Kinerja

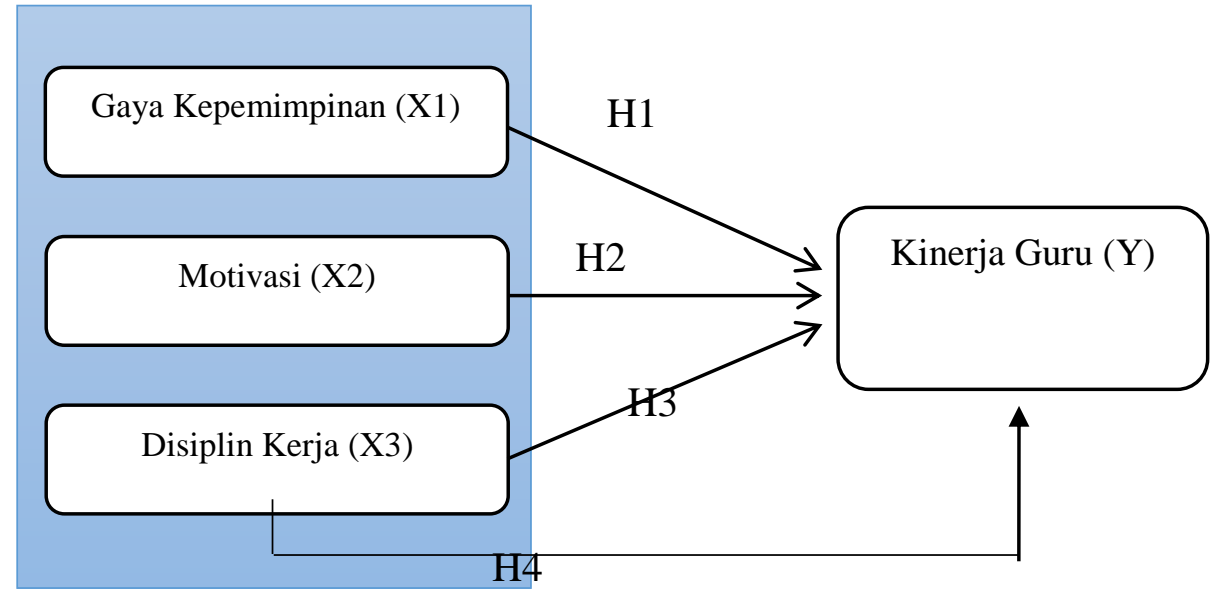

Sumber : Zesbendri dan Aryanti, 2009 


\section{Hipotesis}

Berdasarkan kerangka

pemikiran, maka beberapa hipotesis untuk penelitian ini dipaparkan sebagai berikut:

H1: Diduga kepemimpinan secara parsial berpengaruh positif terhadap kinerja guru SMK Farmasi Ikasari Pekanbaru

H2: Diduga motivasi secara parsial berpengaruh positif terhadap kinerja guru SMK Farmasi Ikasari Pekanbaru.

H3: Diduga disiplin kerja secara parsial berpengaruh positif terhadap kinerja guru SMK Farmasi Ikasari Pekanbaru.

H4: Diduga kepemimpinan, motivasi dan disiplin kerja secara bersama-sama berpengaruh positif terhadap kinerja guru SMK Farmasi Ikasari Pekanbaru.

\section{KERANGKA TEORI \\ Kepemimpinan}

Kepuasan adalah perasaan Kepemimpinan dapat mempengaruhi kesuksesan pegawai dalam berprestasi, dan akan berujung pada keberhasilan organisasi dalam mencapai tujuannya. Menurut R.D. Agarwal (1984) dalam Tika (2010:63) mendefinisikan kepemimpinan sebagai seni mempengaruhi orang lain untuk mengarahkan kemauan mereka, kemampuan dan usaha untuk mencapai tujuan pimpinan.

$$
\text { Menurut Rivai, dkk }
$$
(2009:821) pemimpin adalah kunci bagi penerapan perubahan strategi. Peran pemimpin adalah menyusun arah mengkomunikasikan dengan karyawan, memotivasi para karyawan dan melakukan tinjauan jangka panjang.

\section{Motivasi (Motivation)}

Flippo dalam Melayu (2007:143) mengungkapkan bahwa motivasi adalah suatu keahlian, dalam mengarahkan pegawai dan organisasi agar mau bekerja secara berhasil, sehingga keinginan para pegawai dan tujuan organisasi sekaligus tercapai.

$\begin{array}{ccc}\text { Menurut } & \text { Greenberg dan } \\ \text { Baron dalam Danang dan }\end{array}$
Burhanudin (2011:27) motivasi didefinis ikan sebagai serangkaian proses yang menggerakkan, mengarahkan, dan mempertahankan perilaku individu untuk mencapai beberapa tujuan.

Motivasi menurut Robins dan Caulter dalam Komang, wayan dan Sriati (2009:30) adalah kesediaan untuk mengeluarkan tingkat upaya yang tinggi untuk tujuan organisasi yang di kondisikan oleh Disiplin Kerja upaya itu dalam memenuhi beberapa kebutuhan individu tertentu.

\section{Disiplin Kerja}

Menurut Rivai, vetrizal dan Sagala, Ella Jauvani (2009:825) disiplin kerja adalah suatu alat yang digunakan manajer untuk berkomunikasi dengan karyawan agar mereka bersedia untuk mengubah suatu perilaku serta sebagai upaya untuk meningkatkan kesadaran dan kesedian seseorang mentaati semua peraturan perusahaan dan norma-norma yang berlaku.

Sedangkan menurut Hasibuan (2009:193), kedisiplinan adalah fungsi operatif keenam dari manajemen sumber daya manusia yang merupakan kesadaran dan kesediaan seseorang mentaati semua peraturan institusi dan norma-norma social yang berlaku. Disiplin yang 
baik akan mencerminkan tanggung jawab seseorang terhadap tugastugas yang diberikan kepadanya.

\section{Kinerja Guru}

Menurut Hasibuan (2007:94)

Kinerja/ prestasi adalah suatu hasil kerja yang dicapai seseorang dalam melaksanakan tugas-tugas yang dibebankan kepadanya yang didasarkan atas kecakapan, pengalaman dan kesungguhan serta waktu. Hasil kerja yang dicapai oleh seorang karyawan haruslah dapat memberikan konstribusi yang penting bagi perusahaan yang dilihat dari segi kualitas dan kuantitas yang dirasakan oleh perusahaan dan sangat besar manfaatnya bagi kepentingan perusahaan dimasa sekarang dan yang akan datang.

Selanjutnya menurut Handoko dalam Tika (2010:121) mengatakan bahwa kinerja sebagai proses dimana organisasi mengevaluasi atau menilai prestasi kerja guru.

Sedangkan Pengertian kinerja guru adalah hasil kerja yang dilihat dari serangkaian kemampuan yang dimiliki seorang guru. Kemampuan yang harus dimiliki seorang guru telah disebutkan dalam undangundang guru dan dosen no. 14 tahun 2005 pasal 8 yaitu Guru wajib memiliki kualifikasi akademik, kompetensi, sertifikat pendidik, sehat jasmani dan rohani, serta memiliki kemampuan untuk mewujudkan tujuan pendidikan nasional. Berikutnya pada pasal 10 ayat 1 bahwa Kompetensi guru sebagaimana dimaksud dalam Pasal 8 meliputi kompetensi pedagogik, kompetensi kepribadian, kompetensi sosial, dan kompetensi profesional yang diperoleh melalui pendidikan profesi. Keempat kompetensi tersebut terintegrasi dalam kinerja guru.

\section{METODE PENELITIAN \\ Lokasi dan Waktu Penelitian}

Lokasi penelitian ini dilakukan di SMK Farmasi Ikasari Pekanbaru dengan alamat Jalan Bangau Sakti/ Mawar No. 98 Kelurahan Simpang Baru Kecamatan Tampan-Pekanbaru.

\section{Jenis dan Sumber Data}

Jenis data yang digunakan pada penelitian ini adalah Data Primer dan Data Sekunder, Data Primer merupakan sumber data yang diperoleh secara langsung dari SMK Farmasi Ikasari Pekanbaru sedangkan Data Sekunder adalah data yang diperoleh penulis dalam bentuk sudah jadi, tabel-tabel, daftar dan gambar yang diperoleh dari buku-buku ilmiah yang berhubungan dengan penelitian.

\section{Populasi dan Sampel}

Populasi dalam penelitian ini adalah guru SMK Farmasi Ikasari Pekanbaru yang berjumlah 55 orang yang terdiri dari guru tetap 27 orang dan guru tidak tetap 28 orang, dan Sampel penelitian ini adalah 55 orang guru SMK Farmasi Ikasari Pekanbaru.

\section{Teknik Pengumpulan Data}

Metode pengumpulan data yang digunakan penulis dalam penelitian ini yaitu Interview, Yaitu melakukan wawancara langsung dengan guru SMK Farmasi Ikasari Pekanbaru dan Kuesioner, yaitu merupakan pengumpulan data yang dilakukan dengan cara memberi pertanyaan tertulis kepada responden. 


\section{Teknik Analisa Data}

Analisis data dalam
penelitian ini adalah analisis deskriptif untuk variabel yang bersifat kualitatif dan analisis induktif/ kuantitatif untuk pengujian hipotesis dengan menggunakan uji statitistik yang dibantu dengan penggunaan perhitungan statistik komputerisasi melalui bantuan program komputer dari Statistical Package For Social Science (SPSS).

\section{IV.HASIL PENELITIAN \& PEMBAHASAN}

Berdasarkan hasil penelitian, yang telah dilakukan maka, pengujian hipotesis dapat dijelaskan sebagai berikut :

\section{Uji Hipotesis 1 :}

Kepemimpinan berpengaruh positif dan signifikan terhadap Kinerja guru SMK Farmasi Ikasari Pekanbaru, terbukti dari nilai signifikan $<0,05$ maka Ho ditolak dan Ha diterima.

\section{Uji Hipotesis 2 :}

Motivasi berpengaruh positif dan signifikan terhadap Kinerja guru SMK Farmasi Ikasari Pekanbaru yang dibuktikan dari nilai signifikan $<0,05$ maka Ho ditolak dan $\mathrm{Ha}$ diterima.

\section{Uji Hipotesis 3 :}

Disiplin Kerja berpengaruh positif dan signifikan terhadap Kinerja guru SMK Farmasi Ikasari Pekanbaru dibuktikan dengan nilai signifikan < 0,05 maka Ho ditolak dan $\mathrm{Ha}$ diterima.

\section{Uji Hipotesis 4 :}

Kepemimpinan, Motivasi dan Disiplin Kerja secara bersama-sama berpengaruh positif dan signifikan terhadap Kinerja guru SMK Farmasi
Ikasari Pekanbaru, yang dibuktikan dengan nilai signifikan $<0,05$ maka Ho ditolak dan Ha diterima.

\section{PEMBAHASAN}

\section{Pengaruh Kepemimpinan, Motivasi, dan Disiplin Kerja Terhadap Kinerja Guru SMK Farmasi Ikasari Pekanbaru}

Hasil penelitian menunjukkan bahwa secara bersama-sama terdapat pengaruh yang signifikan antara kepemimpinan, motivasi dan disiplin kerja terhadap kinerja guru SMK Farmasi Ikasari Pekanbaru. Dari persamaan yang dihasilkan dapat diartikan semakin baik kepemimpinan dari kepala sekolah, dan semakin baik motivasi yang diberikan serta semakin baik disiplin kerja guru maka akan meningkatkan kinerja guru pada SMK Farmasi Ikasari Pekanbaru. Sumbangan secara bersama-sama antara variabel kepemimpinan, motivasi dan disiplin kerja terhadap kinerja guru sebesar $56,7 \%$ dan sisanya $43,3 \%$ di pengaruhi oleh factor lain yang tidak diteliti dalam penelitian ini.

\section{Pengaruh Motivasi Terhadap Kinerja Guru SMK Farmasi Ikasari Pekanbaru}

Hasil pengujian hipotesis penelitian yang menyatakan "Terdapat pengaruh positif dan signifikan dari variabel motivasi terhadap kinerja guru SMK Farmasi Ikasari Pekanbaru" terbukti kebenarannya. Hal ini ditunjukkan dengan koefisien regresi sebesar 0,185 dan tingkat signifikasi sebesar 0,040 lebih kecil dari alpha 5\%. Hal ini berarti semakin baik motivasi yang diberikan dapat meningkatkan kinerja guru SMK Farmasi Ikasari Pekanbaru. 


Untuk meningkatkan kinerja
guru SMK Farmasi Ikasari
Pekanbaru hanya
pengaruhnya dari factor motivasi,
namun demikian tetap harus di
perhatikan, baik secara finansial
maupun non finansial.

\section{Pengaruh Disiplin Kerja Terhadap Kinerja Guru SMK Farmasi Ikasari Pekanbaru}

Hasil pengujian hipotesis yang menyatakan bahwa "Terdapat pengaruh yang positif dan signifikan antara variabel disiplin kerja terhadap kinerja guru" terbukti kebenarannya. Hal ini ditunjukkan dengan koefisien regresi sebesar 0,376 dan tingkat signifikasi 0,000 lebih kecil dari alpha 5\%. Hal ini berarti semakin tinggi disiplin kerja akan meningkatkan kinerja guru SMK Farmasi Ikasari Pekanbaru. Jika seorang guru disiplin dalam setiap pekerjaan yang diberikan, baik dating dan pulang tepat waktu serta mematuhi peraturan yang telah ditetapkan oleh pimpinan, maka kinerja guru tersebut akan menjadi maksimal.

Berdasarkan pembahasan
diatas maka dapat disimpulkan
bahwa variabel yang memiliki
pengaruh yang paling besar adalah
variabel Disiplin kerja, hal ini dapat
dilihat dari nilai signifikan 0,000 atau
dari besarnya nilai t hitung sebesar
3,796. Sedangkan yang memiliki
pengaruh yang sedikit adalah

variabel kepemimpinan. Maka hendaknya kepala sekolah harus memperhatikan kepemimpinannya, guna meningkatkan kinerja Guru.

\section{Pengaruh \\ Kepemimpinan Terhadap Kinerja Guru SMK Farmasi Ikasari Pekanbaru}

Hasil pengujian hipotesis penelitian yang menyatakan bahwa "Terdapat pengaruh positif dan signifikan dari variabel kepemimpinan terhadap kinerja guru SMK Farmasi Ikasari Pekanbaru terbukti kebenarannya. Hal ini ditunjukkan dengan besarnya koefisien regresi sebesar 0,149 dan tingkat signifikasi 0,048 lebih kecil dari alpha 5\%. Hal ini berarti kinerja guru SMK Farmasi Ikasari Pekanbaru dipengaruhi secara positif dan signifikan oleh kepemimpinan yang diterapkan dan dilaksanakan oleh kepala sekolah. Jika kepala sekolah memiliki kemampuan untuk mempengaruhi, membimbing, mengarahkan dan memfasilitasi bawahan agar mau berbuat dan bekerja sesuai dengan ketentuan yang berlaku, maka kinerja guru SMK Farmasi Ikasari Pekanbarui akan cenderung maksimal.

Berdasarkan Uji hipotesis yang digunakan dalam penelitian ini yaitu uji koefisien determinasi, uji F, uji $t$ dan uji regresi linear berganda. Untuk melihat hasil uji hipotesis dapat dilihat pada tabel 4 berikut: 


\section{Tabel 4}

Hasil Uji Hipotesis Koefisien Determinasi, Uji F, Uji t dan Uji Regresi Linear berganda Coefficients $^{a}$

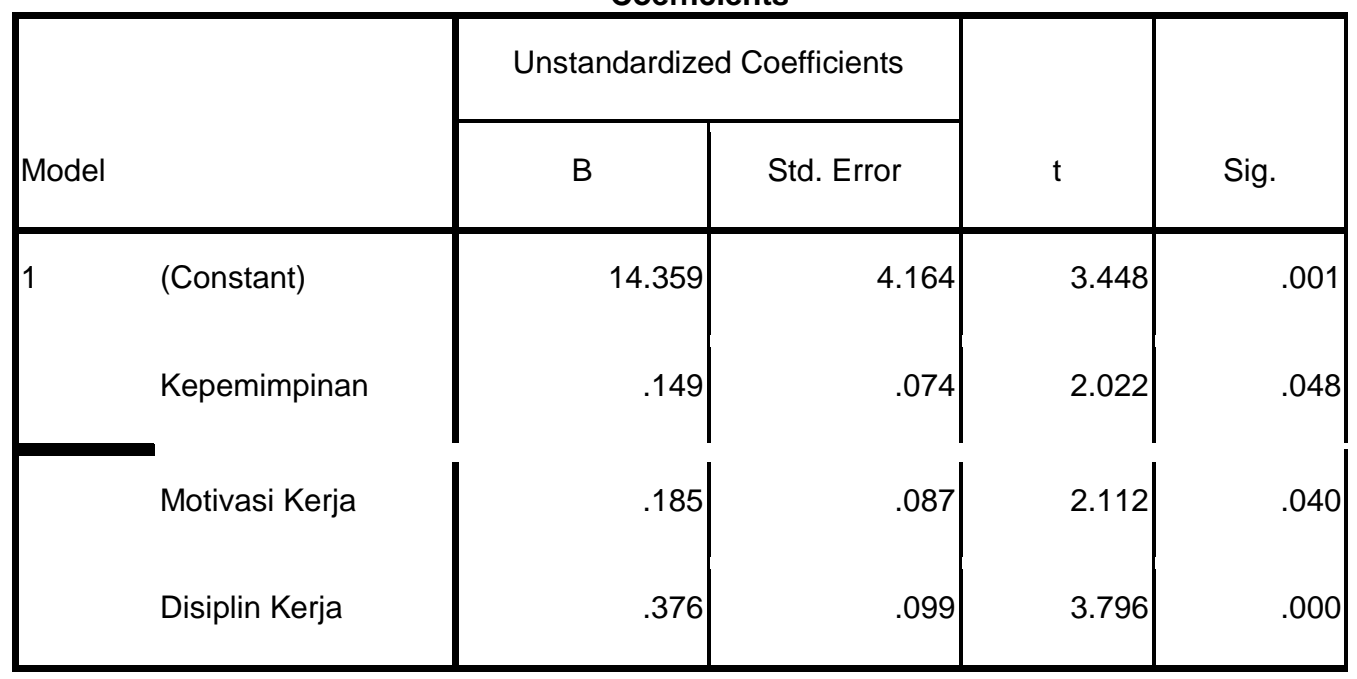

a. Dependent Variable: Kinerja Guru

\section{SIMPULAN DAN SARAN}

\section{Simpulan}

1. Kepemimpinan berpengaruh positif dan signifikan terhadap kinerja guru SMK Farmasi Ikasari Pekanbaru dengan koefisien regresi 0,149 dan tingkat signifikan 0,048.

2. Motivasi berpengaruh positif dan signifikan terhadap kinerja guru SMK Farmasi Ikasari Pekanbaru dengan koefisien regresi 0,185 dan tingkat signifikan 0,040.

3. Disiplin kerja berpengaruh positif dan signifikan terhadap kinerja guru SMK Farmasi Ikasari Pekanbaru dengan koefisien regresi 0,376 dan tingkat signifikan 0,000 .

4. Kepemimpinan, motivasi dan disiplin kerja secara serentak berpengaruh signifikan terhadap kinerja guru SMK Farmasi Ikasari Pekanbaru dengan tingkat signifikan 0,000 .

\section{Saran}

Berdasarkan kesimpulan di atas, maka dapat diberikan beberapa saran sebagai berikut:

1. Kepemimpinan harus ditingkatkan berupa pemberian fasilitas yang cukup kepada dewan guru agar kinerja guru dapat maksimal sesuai dengan harapan organisasi.

2. Disiplin kerja harus ditingkatkan berupa sanksi yang kuat bagi guru SMK Farmasi Ikasari Pekanbaru yang melanggar peraturan yang sudah ditetapkan pimpinan agar dapat memaksimalkan kinerja guru lebih baik dari sebelumnya.

3. Motivasi berupa pemenuhan kebutuhan para guru SMK Farmasi Ikasari Pekanbaru harus lebih diperhatikan lagi guna meningkatkan kinerja guru lebih baik lagi. 
4. Kepemimpinan, motivasi dan disiplin kerja harus lebih ditingkatkan agar kinerja guru SMK Farmasi Ikasari Pekanbaru semakin maksimal.

\section{DAFTAR PUSTAKA}

Ardana, I Komang, Ni Wayan Mujiati dan IWayan Mudiartha Utama. 2011. Manajemen Sumber Daya Manusia. Edisi Pertama : Graha Ilmu.

Danang dan Burhanudin. 2011.Perilaku Organisasional. Yogyakarta. Caps.

Hasibuan, Malayu S.P 2007, Manajemen Sumber Daya Manusia Perusahaan,. Bandung, PT. Bumi Aksa.

Hasibuan, Melayu. 2009. Manajemen Sumber Daya Manusia edisi revisi. Jakarta. Bumi Aksara

Hasibuan, Melayu 2008. Organisasi \& Motivasi. Jakarta. PT. Bumi Aksara

Komang, Mujiati \& Sriathi. 2009. Perilaku Keorganisasian. Edisi 2. Denpasar. Graha Ilmu.

Kotler, dan Keller (2012), manajemen pemasaran, Edisi 12. Penerbit Erlangga, Jakarta

Notoatmodjo, Soekidjo. 2009. Pengembangan Sumber Daya Manusia. Jakarta. Rineka Cipta.

Rachmawati, Warella, Zaenal Hidayat. (2006). Pengaruh
Motivasi Kerja, Kemampuan Kerja dan Gaya Kepemimpinan terhadap Kinerja Karyawan pada Badan Kesatuan Bangsa dan Perlindungan Masyarakat Propinsi Jawa Tengah. Jurnal Ilmu Administrasi dan Kebijakan Publik. 3(1): 8997.

Rivai, Vethrizal dan Sagala, Ella Jauvani. (2009) Edisi Kedua Manajemen Sumber Daya Manusiauntuk Perusahaan dari Teori ke Praktik. Rajawali Press. Jakarta.

Shadare, Oluseyi .A and Hammed, T. Ayo. 2009. "Influence of Work Motivation, Leadership Effectiveness and Time Management on Employees' Performance in Some Selected Industries in Ibadan, Oyo State, Nigeria". European Journal of Economics. 1(16): pp: 8-17.

Tika,Moh.Pabundu. 2010. Budaya Organisasi dan Peningkatan Kinerja Perusahaan. Bumi Aksara. Jakarta.

Thoha, $\quad$ Mitfah. 2010. Kepemimpinan dalam Manajemen Suatu Pendeka tan Perilaku, Cetakan Kesembilan. Jakarta : Penerbit PT Raja Grafindo Persada.

Zesbendri \& Ariyanti, Anik, 2009, Pengaruh Disiplin kerja terhadap kinerja pegawai pada kantor badan pusat statistik kabupaten bogor. 